\title{
FORMULASI SEDIAAN LOTION MENGGUNAKAN KOLAGEN TULANG IKAN PATIN (PANGASIUS SP) SEBAGAI PELEMBAB KULIT
}

\author{
Hepni \\ Program Studi Sarjana Farmasi, STIKes Arjuna \\ E-mail : hepni.bagariang89@gmail.com
}

\begin{abstract}
Background: In general, people consume catfish meat as a source of protein and a high content of omega 3, while the bones are disposed of as waste. Collagen is a protein derivative that has the effect of maintaining skin elasticity. Objective: To find out whether the catfish bone collagen can be formulated into lotions which in certain consentration can moisturize and do not irritate the skin. Method: Extraction of collagen from catfish bones, characterization of collagen by infrared spectrophotometry, making collagen lotion of catfish bones with a concentration of $1 \%, 1.5 \%$, $2.5 \%, 3.5 \%$ and evaluation of collagen lotion preparations and test the ability of the preparation to moisturize. skin using a Skin moisturizer detector (SG-7D $\square$ ) and the results were tested statistically using the ANOVA test with SPSS 20 Free trial. Result: Catfish bones contained collagen in waves of 3250-3350 cm-1 and 1260-1630 cm-1 which indicated the presence of amine and amide groups. The statistical test results show the probability is smaller than 0.05 . The highest humidity was in the FE formula which contained $3.5 \%$ collagen with a moisture percentage of $53.0 \%$ with a level of "Moist" but lower than the lotions on the market with a percentage of $54.3 \%$. Conclusion: Catfish bone collagen can be formulated into oil-in-water (M/A) emulsion type lotion. Keywords: Catfish bones, Collagen, Lotion, Skin moisturizer.
\end{abstract}

\begin{abstract}
Abstrak
Pendahuluan: Secara umum masyarakat mengkonsumsi daging ikan patin sebagai sumber protein dan kandungan omega 3 yang tinggi, sedangkan tulangnya dibuang sebagai limbah. Kolagen merupakan salah satu turunan protein yang mempunyai efek untuk mempertahankan kekenyalan kulit. Tujuan: Untuk mengetahui apakah kolagen tulang ikan patin dapat diformulasikan kedalam sediaan lotion yang dalam konsentrasi tertentu dapat melembabkan dan tidak mengiritasi kulit. Metode: Ekstraksi kolagen dari tulang ikan patin, karakterisasi kolagen dengan spektrofotometri inframerah, pembuatan lotion kolagen tulang ikan patin dengan konsentrasi 1\%, 1,5\%, 2,5\%, 3,5\% dan evaluasi sediaan lotion kolagen serta uji kemampuan sediaan melembabkan kulit memakai alat Skin moisturizer detector (SG-7D ${ }^{\square}$ ) serta hasilnya diuji secara statistik memakai uji ANOVA dengan SPSS 20 Free trial. Hasil: Tulang ikan patin mengandung kolagen pada gelombang 3250$3350 \mathrm{~cm}^{-1}$ dan $1260-1630 \mathrm{~cm}^{-1}$ yang menunjukkan adanya gugus amina dan amida. Hasil uji statistik menunjukkan probabilitas lebih kecil dari 0,05. Kelembaban tertinggi yaitu pada formula FE yang mengandung 3,5\% kolagen dengan persentase kelembaban 53,0\% dengan level "Lembab" tetapi lebih rendah dari lotion yang beredar dipasaran dengan persentase sebesar 54,3\%. Kesimpulan: Kolagen tulang ikan patin dapat diformulasi menjadi sediaan lotion tipe emulsi minyak dalam air (M/A).
\end{abstract}

Kata kunci: Tulang ikan patin, Kolagen, Lotion, Pelembab kulit. 


\section{PENDAHULUAN}

Ikan patin adalah jenis ikan konsumsi air tawar asli Indonesia yang tersebar di sebagian wilayah Sumatera dan Kalimantan. Daging ikan patin memiliki kandungan kalori dan protein yang cukup tinggi, rasa dagingnya khas, enak, lezat dan gurih sehingga digemari oleh masyarakat. Ikan patin dinilai lebih aman untuk kesehatan karena kadar kolesterolnya rendah dibandingkan dengan daging hewan ternak. Selain itu ikan patin memilki beberapa kelebihan lain, yaitu ukuran per individunya besar dan di alam panjangnya bisa mencapai $120 \mathrm{~cm}$ (Susanto, et al,. 2008).

Walaupun patin dikenal ikan yang mampu hidup pada lingkungan perairan yang jelek, namun ikan ini lebih menyukai perairan dengan kondisi perairan baik (Kordi, 2005).

Kolagen adalah suatu protein struktural yang panjang dan berserat yang berisi tiga rantai peptida, yang membentuk struktur heliks rangkap tiga oleh ikatan hidrogen intra-molekuler antara Gly dan Hyp dalam rantai yang berdekatan (Zeugolis dalam Hua-Jie Wang, et al., 2009). Terdapat banyak tipe kolagen penyusun jaringan, antara lain tipe I kolagen ditemukan terutama pada kulit, tulang dan tendon, tipe II kolagen ditemukan pada tulang rawan arteri pada tulang sendi, dan tipe III kolagen merupakan unsur utama dari pembuluh darah (Cahyanto, 2009).

Kolagen adalah protein yang paling berlimpah dalam jaringan hewan dengan proporsi $30 \%$ dari total protein tubuh sebagai komponen utama dari jaringan ikat, otot, gusi dan kulit (Kittiphattanabawon, et al., 2005).

Kosmetik adalah sediaan atau paduan bahan yang siap untuk digunakan pada bagian luar badan (epidermis, rambut, kuku, bibir, dan organ kelamin bagian luar), gigi dan rongga mulut untuk membersihkan, menambah daya tarik, mengubah penampakan, melindungi supaya tetap dalam keadaan baik, memperbaiki bau badan tetapi tidak dimaksudkan untuk mengobati atau menyembuhkan penyakit (Iswari, 2007)
Kosmetik pelembab merupakan
kosmetik yang mempertahankan struktur dan fungsi kulit dari berbagai pengaruh seperti udara kering, sinar matahari terik, angin keras, usia lanjut dan berbagai penyakit kulit maupun penyakit dalam tubuh yang mempercepat penguapan air sehingga kulit menjadi kering (Wasitaatmadja, 1997).

Dalam bidang kosmetik, lotion adalah emulsi yang terdiri dari sedikitnya dua fase yang tidak tercampur yaitu fase minyak dan fase air yang distabilkan oleh emulgator, mengandung satu atau lebih bahan aktif didalamnya (Wilkinson, 1982).

Perawatan kulit penting untuk melindungi kulit dari kerusakan. Salah satu hal yang esensial dalam perawatan kulit adalah melindungi kulit dari dehidrasi. Kulit yang mengalami dehidrasi akan cepat berkerut dan tampak kusam, sehingga pelembaban merupakaan salah satu langkah penting dalam rangkaian kegiatan perawatan kulit. Pelembab berfungsi untuk melindungi kulit dari dehidrasi, sehingga kulit tampak lembut, segar dan cerah. Salah satu bentuk sediaan pelembab kulit adalah lotion (Muliyawan, et al., 2002).

Berdasarkan latar belakang diatas maka peneliti tertarik untuk melakukan penelitian tentang formulasi sediaan lotion menggunakan kolagen tulang ikan patin sebagai pelembab kulit sehingga dapat memanfaatkan limbah tulang ikan patin menjadi bahan yang bernilai jual.

\section{METODE PENELITIAN}

\section{Bahan}

Bahan yang digunakan dalam penelitiaan ini adalah tulang ikan patin, larutan dapar $\mathrm{pH}$ asam $(\mathrm{pH} 4,01)$, larutan dapar $\mathrm{pH}$ netral $(\mathrm{pH} 7,01)$, bahan kimia pro analisis yaitu $\mathrm{NaOH} 0,1 \mathrm{M}, \mathrm{CH}_{3} \mathrm{COOH} 0,5$ $\mathrm{M}$ dan bahan kimia selain pro analisis yaitu asam stearat, setil alkohol, metil paraben, propil paraben, trietanolamin, metil biru dan green tea essence.

Peralatan yang digunakan pada penelitian ini adalah Skin moisturizer detector $\quad\left(\mathrm{SG}-7 \mathrm{D}^{\square}\right), \quad$ Neraca 
Digital (AND HT-120 ), Spektrofotometer Infrared Agilent, blender, lemari pengering, penangas air, ayakan mesh 100, pisau, pH meter (ATC), termometer dan alat alat gelas laboratorium.

Sukarelawan yang dijadikan panelis pada uji kemampuan sediaan untuk melembabkan kulit berjumlah 20 orang dan uji iritasi berjumlah 10 orang dengan kriteria sebagai berikut : 1) Wanita, 2) Sehat Jasmani dan Rohani, 3) Usia 20-30 tahun, 4) Tidak ada riwayat penyakit yang berhubungan dengan alergi. Sukarelawan adalah orang terdekat dan sering berada di sekitar pengujian sehingga lebih mudah diawasi dan diamati bila ada reaksi yang terjadi pada kulit yg diuji dan tidak menggunakan produk apapun selama pengujian.

Dasar lotion dibuat berdasarkan formulasi yang menggunakan tipe dasar lotion minyak dalam air. Formulasi dasar lotion (Voigt, 1995) yang digunakan sebagai berikut :

\begin{tabular}{lll}
\hline $\mathbf{R} /$ & Setil Alkohol & $\mathbf{0 , 5}$ \\
& Gliserin & 5 \\
\hline Parafin cair & 7 \\
\hline Trietanolamin & 1 \\
\hline Metil Parabean & 0,1 \\
\hline Propil Paraben & 0,1 \\
\hline Asam Stearat & 2,5 \\
\hline Pewangi & 3 tetes \\
\hline Aquadest & 10 \\
\hline
\end{tabular}

Formula dasar lotion yang dimodifikasi

\begin{tabular}{|c|c|c|}
\hline$\underline{\mathbf{R} /}$ & Setil Alkohol & $\mathbf{0 , 5}$ \\
\hline & Trietanolamin & 1 \\
\hline & Kolagen tulang ikan patin & $\mathrm{X}$ \\
\hline & Metil Parabean & 0,1 \\
\hline & Propil Paraben & 0,1 \\
\hline & Asam Stearat & 2,5 \\
\hline & Pewangi green tea essence & 3 tetes \\
\hline
\end{tabular}

\begin{tabular}{ccc}
\hline Pewarna & 3 tetes \\
\hline Aquadest & ad & 100 \\
\hline Keterangan: & &
\end{tabular}

Keterangan :

$\mathrm{x}=$ Konsentrasi kolagen tulang ikan patin $(1 \%, 1,5 \%, 2,5 \%, 3,5 \%)$

Tulang ikan patin yang mengandung kolagen diformulasikan kedalam sediaan lotion pelembab kulit yaitu konsentrasi : $1 \%, 1,5 \%, 2,5 \%, 3,5 \%$ dan lotion pelembab tanpa kolagen tulang ikan patin digunakan sebagai blanko. Formula sediaan lotion kolagen tulang ikan patin dapat dilihat pada tabel dibawah ini :

\begin{tabular}{lccccc}
\hline \multirow{2}{*}{ Komposisi } & \multicolumn{5}{c}{ Formulasi } \\
& lotion (\%) \\
\cline { 2 - 6 } & A & B & C & D & E \\
\hline KTIP & 0 & 1 & 1,5 & 2,5 & 3,5 \\
Asam stearat & 2,5 & 2,5 & 2,5 & 2,5 & 2,5 \\
Setil alkohol & 0,5 & 0,5 & 0,5 & 0,5 & 0,5 \\
Metil parabean & 0,1 & 0,1 & 0,1 & 0,1 & 0,1 \\
Propil parabean & 0,1 & 0,1 & 0,1 & 0,1 & 0,1 \\
Trietanolamin & 1 & 1 & 1 & 1 & 1 \\
Pewangi (tetes) & 3 & 3 & 3 & 3 & 3 \\
Aquadest ad & 100 & 100 & 100 & 100 & 100 \\
\hline
\end{tabular}

Keterangan :

KTIP : Kolagen Tulang Ikan Patin

SLKTIP : Sediaan Lotion Kolagen Tulang

Ikan Patin

FA : Blanko

FB : SLKTIP $1 \%$

FC : SLKTIP $1,5 \%$

FD : SLKTIP 2,5\%

FE : SLKTIP 3,5\%

\section{Pengolahan Sampel}

Pengolahan sampel meliputi pembuatan pembuatan serbuk kolagen tulang ikan patin, rendemen kolagen, pembuatan sediaan basis lotion, dan pembuatan lotion kolagen tulang ikan patin

\section{Pembuatan serbuk kolagen tulang ikan patin}

Ikan patin yang masih segar sebanyak $20 \mathrm{~kg}$ dicuci, kemudian direbus 
selama 40 menit, lalu dipisahkan tulang dari dagingnya. Setelah itu ditimbang dan dicuci dengan aquadest hingga bersih kemudian keringkan. Tulang ikan patin direndam dengan larutan $\mathrm{NaOH} 0,1 \mathrm{M}$ dengan rasio 1:10 selama 6 jam, diletakkan pada pendingin. Tulang ikan direndam kembali dengan larutan $\mathrm{NaOH}$ dengan rasio yang sama dan diletakkan pada pendingin selama 6 jam. Dinetralisasi dengan pencucian menggunakan aquadest hingga $\mathrm{pH} 7$.

Kemudian direndam dengan larutan $\mathrm{CH}_{3} \mathrm{COOH}$ 0,5 $\mathrm{M}$ dengan rasio 1:10 selama 3 hari dan diletakkan pada pendingin. Lalu dicuci menggunakan aquadest hingga $\mathrm{pH}$ 4,6. Setelah itu tulang ikan dikeringkan di lemari pengering pada suhu $36^{\circ} \mathrm{C}$ sampai benarbenar kering. Setelah kering tulang ikan di blender dan di dapat serbuk kolagen (modifikasi penelitian Pringgandini, et al., 2018.

\section{Rendemen kolagen}

Rendemen kolagen diperoleh dari perbandingan berat kering kolagen dengan berat bahan tulang ikan patin. Rendemen dapat diperoleh dengan rumus :

Rendemen Kolagen Ikan Patin $(\%)=$ Berat kering kolagen : berat bahan baku $\mathrm{x}$ $100 \%$

\section{Pembuatan sediaan basis lotion}

Masing masing bahan ditimbang untuk membuat dasar lotion. Dalam cawan penguap dimasukkan asam stearat, dan setil alkohol, kemudian dilebur diatas penangas air sampai meleleh sempurna, didapat massa I. Dalam beaker glass dimasukkan metil paraben, propil paraben dan trietanolamin dilarutkan dengan air panas, maka didapat massa II. Di dalam lumpang, campurkan massa I dan massa II yang masih panas sambil digerus secara konstan, ditambahkan aquadest panas sedikit demi sedikit sampai habis lalu gerus hingga homogen, maka diperoleh dasar lotion (Balsam, 1972).

\section{Pembuatan lotion kolagen tulang ikan patin}

Serbuk kolagen tulang ikan patin ditimbang sesuai dengan konsentrasi masing masing. Kedalam mortir ditambahkan dengan setengah basis lotion, ditambahkan serbuk kolagen tulang ikan patin sesuai dengan konsentrasi masing-masing, gerus dan tambahkan sisa basis lotion dan gerus homogen. Bagan alir pembuatan lotion kolagen tulang ikan patin.

\section{HASIL PENELITIAN DAN PEMBAHASAN \\ Hasil pembuatan lotion kolagen tulang ikan patin}

Sediaan lotion dibuat dengan menggunakan formula standart lotion (Voigt, 1955). Formula standart dimodifikasi dengan penambahan serbuk kolagen tulang ikan patin ke dalam beberapa konsentrasi yaitu $1 \%$, $1,5 \%, 2,5 \%$ dan 3,5\% dan blanko sebagai pelembab kulit. Sediaan yang diperoleh berupa lotion dengan warna hijau, homogen, berbentuk cair dan berbau khas. Gambar hasil pembuatan lotion kolagen tulang ikan patin

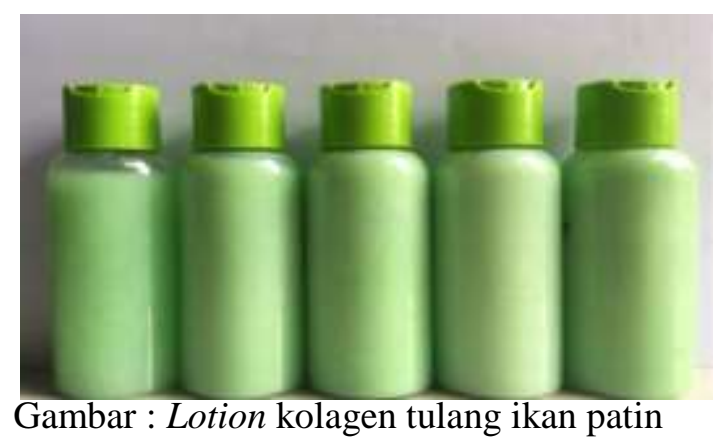

\section{Hasil Karakteristik Tulang Ikan Patin}

Tulang ikan patin diekstraksi terlebih dahulu sehingga diperoleh serbuk kolagen tulang ikan patin yang kemudian dikarakterisasi dengan menggunakan analisis komposisi kimia yaitu analisis kadar air, analisis kadar abu, analisis kadar protein dan analisis kadar lemak. Hasil analisis komposisi kimia kolagen tulang ikan patin yang di uji di Balai Riset dan Standarisasi Industri Medan dapat dilihat pada Tabel 1. 
Tabel 1. Hasil Analisis Komposisi Kimia Kolagen Tulang Ikan Patin yang di uji di Balai Riset dan Standarisasi Industri Medan

\begin{tabular}{ccccc}
\hline No & Parameter & Satuan & Hasil & Syarat \\
\hline 1 & Kadar Air & $\%$ & 6,23 & $\leq$ \\
2 & Kadar Abu & $\%$ & 1,17 & $\leq$ \\
3 & Kadar Protein & $\%$ & 85,1 & $>90 \%$ \\
4 & Kadar Lemak & $\%$ & 5,52 & - \\
\hline
\end{tabular}

Hasil Analisis Gugus Fungsi dengan Fourier Transform Infrared (FTIR)

Tabel 2. Karakteristik Gugus Fungsi Kolagen Tulang Ikan Patin (Pangasius sp.)

\begin{tabular}{llll}
\hline $\begin{array}{l}\text { Jenis } \\
\text { Amida }\end{array}$ & $\begin{array}{l}\text { Wilayah } \\
\text { Serapan } \\
\left(\mathbf{c m}^{-1}\right)\end{array}$ & $\begin{array}{c}\text { Puncak } \\
\text { Serapan }\end{array}$ & Keterangan \\
\hline Amina A & $3400-3440$ & 3270 & Gugus NH \\
\hline Amina B & $2922-2924$ & 2922 & Gugus CH $C_{2}$ \\
\hline Amida I & $1600-1700$ & 1630 & $\begin{array}{l}\text { Gugus karbonil } \\
\text { (ikatan C=O) }\end{array}$ \\
\hline Amida II & $1480-1575$ & 1545 & $\begin{array}{l}\text { NH } \text { sending } \\
\text { NHetching }\end{array}$ \\
\hline Amina III & $1229-1301$ & 1260 & NH bending \\
\hline
\end{tabular}

\section{Hasil Uji Kelembaban Kulit Sukarelawan}

Pengujian dilakukan terhadap 20 orang sukarelawan yg berusia 20-30 tahun. Data Uji Kelembaban dengan menggunakan Alat Skin moistuizer detector (SG-7D ${ }^{\circledR}$ ) dapat dilihat pada Tabel 3.

Tabel 3. Data Uji Kelembaban dengan menggunakan Alat Skin moistuizer detector (SG-7D $\left.{ }^{\circledR}\right)$

\begin{tabular}{|c|c|c|c|c|c|c|c|}
\hline \multirow{2}{*}{$\begin{array}{l}\text { Sukar } \\
\text { elawa } \\
\text { n }\end{array}$} & \multirow{2}{*}{$\begin{array}{c}\text { Rata - } \\
\text { rata } \\
\text { kulit } \\
\text { sebelum } \\
\text { dioleska } \\
\text { n } \\
\text { sediaan }\end{array}$} & \multicolumn{6}{|c|}{$\begin{array}{c}\text { Persentase Rata-Rata } \\
\text { Kelembaban Kulit pada } \\
\text { Masing-Masing Konsentrasi } \\
\text { Sediaan }\end{array}$} \\
\hline & & FA & FB & FC & FD & FE & FF \\
\hline I & $38,7 \%$ & $\begin{array}{c}39,8 \\
\%\end{array}$ & $\begin{array}{c}44,9 \\
\%\end{array}$ & $\begin{array}{c}45,5 \\
\%\end{array}$ & $\begin{array}{c}48,7 \\
\%\end{array}$ & $52,1 \%$ & $54,3 \%$ \\
\hline II & $39,5 \%$ & $\begin{array}{c}40,2 \\
\%\end{array}$ & $\begin{array}{c}46,5 \\
\%\end{array}$ & $\begin{array}{c}47,2 \\
\%\end{array}$ & $\begin{array}{c}49,1 \\
\%\end{array}$ & $53,9 \%$ & $54,3 \%$ \\
\hline
\end{tabular}

\begin{tabular}{|c|c|c|c|c|c|}
\hline III & $36,3 \%$ & $\begin{array}{cc}37,9 & 45,8 \\
\% & \%\end{array}$ & $\begin{array}{c}46,1 \\
\%\end{array}$ & $\begin{array}{c}48,3 \\
\%\end{array}$ & $53,1 \% 54,8 \%$ \\
\hline IV & & $\begin{array}{cc}41,1 & 47,1 \\
\% & \%\end{array}$ & $\begin{array}{c}47,9 \\
\%\end{array}$ & $\begin{array}{c}48,7 \\
\%\end{array}$ & \\
\hline V & & $\begin{array}{cc}37,4 & 46,3 \\
\% & \%\end{array}$ & $\begin{array}{c}47,1 \\
\%\end{array}$ & $\begin{array}{c}50,6 \\
\%\end{array}$ & \\
\hline VI & & $\begin{array}{cc}39,5 & 45,5 \\
\% & \%\end{array}$ & $\begin{array}{c}46,7 \\
\%\end{array}$ & $\begin{array}{c}49,1 \\
\%\end{array}$ & \\
\hline VII & & $\begin{array}{cc}39,8 & 45,8 \\
\% & \%\end{array}$ & $\begin{array}{c}46,4 \\
\%\end{array}$ & $\begin{array}{c}48,9 \\
\%\end{array}$ & \\
\hline VIII & & $\begin{array}{cc}41,5 & 47,9 \\
\% & \%\end{array}$ & $\begin{array}{c}48,9 \\
\%\end{array}$ & $\begin{array}{c}50,7 \\
\%\end{array}$ & \\
\hline IX & & $\begin{array}{cc}39,4 & 46,5 \\
\% & \%\end{array}$ & $\begin{array}{c}47,8 \\
\%\end{array}$ & $\begin{array}{c}50,2 \\
\%\end{array}$ & \\
\hline X & & $\begin{array}{cc}41,3 & 45,2 \\
\% & \%\end{array}$ & $\begin{array}{c}46,1 \\
\%\end{array}$ & $\begin{array}{c}49,5 \\
\%\end{array}$ & \\
\hline XI & & $\begin{array}{cc}37,9 & 44,4 \\
\% & \%\end{array}$ & $\begin{array}{c}45,4 \\
\%\end{array}$ & $\begin{array}{c}48,1 \\
\%\end{array}$ & \\
\hline XII & & $\begin{array}{cc}38,6 & 44,9 \\
\% & \%\end{array}$ & $\begin{array}{c}45,2 \\
\%\end{array}$ & $\begin{array}{c}47,3 \\
\%\end{array}$ & \\
\hline XIII & & $\begin{array}{cc}40,4 & 47,0 \\
\% & \%\end{array}$ & $\begin{array}{c}47,8 \\
\%\end{array}$ & $\begin{array}{c}50,6 \\
\%\end{array}$ & \\
\hline XIV & & $\begin{array}{cc}39,9 & 45,5 \\
\% & \% \\
\end{array}$ & $\begin{array}{c}46,6 \\
\%\end{array}$ & $\begin{array}{c}48,9 \\
\%\end{array}$ & \\
\hline XV & & $\begin{array}{cc}40,1 & 46,4 \\
\% & \%\end{array}$ & $\begin{array}{c}47,5 \\
\%\end{array}$ & $\begin{array}{c}49,8 \\
\%\end{array}$ & 53,8 \\
\hline XVI & & $\begin{array}{cc}39,7 & 44,4 \\
\% & \%\end{array}$ & $\begin{array}{c}45,1 \\
\%\end{array}$ & $\begin{array}{c}48,4 \\
\%\end{array}$ & \\
\hline XVII & & $\begin{array}{cc}41,6 & 47,9 \\
\% & \%\end{array}$ & $\begin{array}{c}48,8 \\
\%\end{array}$ & $\begin{array}{c}49,5 \\
\%\end{array}$ & \\
\hline & & $\begin{array}{cc}41,5 & 46,9 \\
\% & \%\end{array}$ & $\begin{array}{c}47,7 \\
\%\end{array}$ & $\begin{array}{c}50,1 \\
\%\end{array}$ & \\
\hline XIX & & $\begin{array}{cc}38,6 & 46,2 \\
\% & \%\end{array}$ & $\begin{array}{c}47,0 \\
\%\end{array}$ & $\begin{array}{c}49,5 \\
\%\end{array}$ & \\
\hline XX & & $\begin{array}{cc}39,8 & 47,3 \\
\% & \%\end{array}$ & $\begin{array}{c}48,1 \\
\%\end{array}$ & $\begin{array}{c}50,9 \\
\%\end{array}$ & \\
\hline & $38,4 \%$ & $\begin{array}{cc}39,8 & 46,1 \\
\% & \%\end{array}$ & $\begin{array}{c}46,9 \\
\%\end{array}$ & $\begin{array}{c}49,3 \\
\%\end{array}$ & \\
\hline
\end{tabular}

Keterangan :

SLKTIP : Sediaan Lotion Kolagen Tulang Ikan Patin
FA : Sediaan lotion blanko
FB : SLKTIP $1 \%$
FC : SLKTIP $1,5 \%$
FD : SLKTIP $2,5 \%$
FE : SLKTIP 3,5\%
FF : Sediaan lotion pembanding (Citra)

Berdasarkan data pada Tabel 3 diatas menunjukkan bahwa hasil rata-rata kelembaban yang diperoleh dari alat Skin 
moistuizer detector $\left(\mathrm{SG}^{-7 \mathrm{D}^{\circledR}}{ }^{\circledR}\right.$ sebelum dioleskan sediaan lotion adalah $38,4 \%$.

Tabel 4. Hasil Keseluruhan dari RataRata Kelembaban Kulit Sebelum dan Sesudah Menggunakan Lotion Pelembab

\begin{tabular}{|c|c|c|c|c|}
\hline $\begin{array}{l}\text { Rata- } \\
\text { rata } \\
\text { kulit } \\
\text { sebelu } \\
\text { m } \\
\text { diolesk } \\
\text { an } \\
\text { sediaan }\end{array}$ & $\begin{array}{l}\text { For } \\
\text { mula }\end{array}$ & $\begin{array}{l}\text { Skala } \\
\text { kelembaban } \\
\text { alat Skin } \\
\text { moistuizer } \\
\text { detector } \\
\left(\text { SG-7D }{ }^{\circledR}\right)\end{array}$ & $\begin{array}{l}\text { Rata-rata } \\
\text { Setelah } \\
\text { Menggun } \\
\text { akan } \\
\text { lotion }(\%)\end{array}$ & $\begin{array}{l}\text { Skala } \\
\text { kelembaba } \\
\mathbf{n} \\
\text { alat Skin } \\
\text { moistuizer } \\
\text { detector } \\
\left(\text { SG-7D }^{\circledR}\right)\end{array}$ \\
\hline \multirow{6}{*}{38,7} & A & $\begin{array}{l}\text { Kurang } \\
\text { Lembab }\end{array}$ & $39,8 \%$ & $\begin{array}{l}\text { Kurang } \\
\text { Lembab }\end{array}$ \\
\hline & B & $\begin{array}{l}\text { Kurang } \\
\text { Lembab }\end{array}$ & $46,1 \%$ & Lembab \\
\hline & $\mathrm{C}$ & $\begin{array}{l}\text { Kurang } \\
\text { Lembab }\end{array}$ & $46,9 \%$ & Lembab \\
\hline & $\mathrm{D}$ & $\begin{array}{c}\text { Kurang } \\
\text { Lembab }\end{array}$ & $49,3 \%$ & Lembab \\
\hline & $\mathrm{E}$ & $\begin{array}{l}\text { Kurang } \\
\text { Lembab }\end{array}$ & $53,0 \%$ & Lembab \\
\hline & $\mathrm{F}$ & $\begin{array}{l}\text { Kurang } \\
\text { Lembab }\end{array}$ & $54,3 \%$ & Lembab \\
\hline
\end{tabular}

Keterangan

SLKTIP : Sediaan Lotion Kolagen Tulang Ikan Patin

FA : Sediaan lotion blanko

FB : SLKTIP $1 \%$

FC : SLKTIP $1,5 \%$

FD : SLKTIP 2,5\%

FE : SLKTIP 3,5\%

FF : Sediaan lotion pembanding (Citra)

$<40 \%$ : kurang lembab

40-60\% : lembab

$>60 \%$ : sangat lembab

Berdasarkan pada Tabel 4 menunjukkan bahwa pada blanko, lotion kolagen tulang ikan patin pada konsentrasi $1,5 \%, 2,5 \%, 3,5 \%$ dan lotion pembanding terlihat bahwa formula dapat memberikan efek "lembab" pada kulit sedangkan pada blanko memberikan efek "kurang lembab" pada kulit. Karena berdasarkan referensi alat Skin moisturizer detector dinyatakan bahwa jika lebih kecil dari $40 \%$ yaitu kurang lembab, 40-60\% yaitu lembab dan lebih besar dari $60 \%$ yaitu sangat lembab.

Tabel 5 Hasil Analisis Statistik Uji Tukey HSD

\begin{tabular}{|c|c|c|c|c|c|c|c|}
\hline \multirow{2}{*}{ Formula } & \multirow{2}{*}{$\mathbf{N}$} & \multicolumn{6}{|c|}{ Subset for alpha $=0,05$} \\
\hline & & 1 & 2 & 3 & 4 & 5 & 6 \\
\hline Kondisi & & 38,47 & & & & & \\
\hline Awal & 20 & 5 & & & & & \\
\hline Formula & & & 39,80 & & & & \\
\hline A & 20 & & 0 & & & & \\
\hline Formula & & & & 46,13 & & & \\
\hline $\mathrm{B}$ & 20 & & & 5 & & & \\
\hline Formula & & & & 46,94 & & & \\
\hline $\mathrm{C}$ & 20 & & & 5 & & & \\
\hline Formula & & & & & 49,34 & & \\
\hline $\mathrm{D}$ & 20 & & & & 5 & & \\
\hline Formula & & & & & & 53,01 & \\
\hline $\mathrm{E}$ & 20 & & & & & 0 & \\
\hline Formula & & & & & & & 54,34 \\
\hline $\mathrm{F}$ & 20 & & & & & & 5 \\
\hline Sig. & & 1,000 & 1,000 & ,319 & 1,000 & 1,000 & 1,000 \\
\hline
\end{tabular}

Dari uji Post-Hoc menggunakan Tukey $H S D$ dapat disimpulkan bahwa :

1. Nilai rata-rata kelembaban kondisi kulit awal $(38,475 \pm 1,9268)$ memiliki perbedaan yang signifikan dengan seluruh konsentrasi formula dengan probabilitas 0,000 dan 0,009 .

2. Formula A $(39,800 \pm 1,2503)$ mempunyai perbedaan nilai rata rata kelembaban yang signifikan dengan kondisi kulit awal $(38,475 \pm 1,9268)$, formula B $(46,135 \pm$ $1,0624)$, formula $C(46,945 \pm 1,1418)$, formula $\mathrm{D}(49,345 \pm 0,9747)$, formula $\mathrm{E}$ $(53,010 \pm 0,9352)$ dan formula $\mathrm{F}$ (pembanding) $(54,345 \pm 0,4628)$ dengan probabilitas 0,000 dan 0,009 .

3. Formula B $(46,135 \pm 1,0624)$ mempunyai perbedaan nilai rata-rata kelembaban yang signifikan dengan kondisi kulit awal $(38,475 \pm 1,9268)$, formula A $(39,800 \pm$ $1,2503)$, formula $\mathrm{D}(49,345 \pm 0,9747)$, formula $\mathrm{E}(53,010 \pm 0,9352)$ dan formula $\mathrm{F}$ (pembanding) $(54,345 \pm 0,4628)$ dengan probabilitas 0,000 . Tetapi tidak mempunyai perbedaan yang signifikan dengan formula $C(46,945 \pm 1,1418)$.

4. Formula $C(46,945 \pm 1,1418)$ mempunyai perbedaan nilai rata-rata kelembaban yang 
signifikan dengan kondisi kulit awal $(38,475 \pm 1,9268)$, formula A $(39,800 \pm$ $1,2503)$, formula $\mathrm{D}(49,345 \pm 0,9747)$, formula $\mathrm{E}(53,010 \pm 0,9352)$ dan formula $\mathrm{F}$ (pembanding) $(54,345 \pm 0,4628)$ dengan probabilitas 0,000 . Tetapi tidak mempunyai perbedaan yang signifikan dengan formula B $(46,135 \pm 1,0624)$.

5. Formula $D(49,345 \pm 0,9747)$ mempunyai perbedaan nilai rata-rata kelembaban yang signifikan dengan kondisi kulit awal $(38,475 \pm 1,9268)$, formula A $(39,800 \pm$ $1,2503)$, formula $B(46,135 \pm 1,0624)$, formula $\mathrm{C}(46,945 \pm 1,1418)$, formula $\mathrm{E}$ $(53,010 \pm 0,9352) \mathrm{d}$

6. Formula $\mathrm{E}(53,010 \pm 0,9352)$ mempunyai perbedaan nilai rata-rata kelembaban yang signifikan dengan kondisi kulit awal $(38,475 \pm 1,9268)$, formula A $(39,800 \pm$ $1,2503)$, formula B $(46,135 \pm 1,0624)$, formula C $(46,945 \pm 1,1418)$, formula $\mathrm{D}$ $(49,345 \pm 0,9747)$, dan formula $F$ (pembanding) $(54,345 \pm 0,4628)$ dengan probabilitas 0,000 dan 0,009 .

7. Formula F (pembanding) (54,345 \pm $0,4628)$ mempunyai perbedaan nilai ratarata kelembaban yang signifikan dengan kondisi kulit awal $(38,475 \pm 1,9268)$, formula A $(39,800 \pm 1,2503)$, formula B $(46,135 \pm 1,0624)$, formula C $(46,945 \pm$ $1,1418)$, formula $\mathrm{D}(49,345 \pm 0,9747)$, dan formula $\mathrm{E}(53,010 \pm 0,9352)$ dengan probabilitas 0,000 dan 0,009 .

\section{KESIMPULAN}

Berdasarkan hasil penelitian yang telah dilakukan terhadap kolagen tulang ikan patin (Pangasius sp.) dapat disimpulkan bahwa: Tulang ikan patin mengandung kolagen yang diuji menggunakan alat Fourier Transform Infared (FTIR) dengan panjang gelombang $3250-3350 \mathrm{~cm}^{-1}$ dan $1260-1630$ $\mathrm{cm}^{-1}$ yang menunjukkan adanya gugus amina dan amida.

Kolagen tulang ikan patin dapat diformulasikan kedalam sediaan lotion dengan tipe emulsi minyak dalam air (M/A), seluruh sediaan merupakan sediaan homogen dan stabil serta tidak mengiritasi kulit, dengan rentang $\mathrm{pH} 6,3$ pada saat selesai dibuat, dan rentang $\mathrm{pH}$ 6,0-6,3 setelah penyimpanan selama 12 minggu serta semua sediaan menunjukkan perbedaan yang signifikan kecuali pada formula B dan dan formula C. Semua formula melembabkan kulit pada level "lembab" yaitu pada rentang $46,1 \%$ - 54,3\%. Pada formula FE yaitu sediaan lotion pelembab yang mengandung kolagen tulang ikan patin pada konsentrasi $3,5 \%$ merupakan formula yang paling melembabkan kulit dengan persentase 3 menunjukkan level "Lembab" tetapi lebih rendah dari lotion yang beredar dipasaran yang memberikan persentase sebesar 3 dengan level "Lembab".

\section{SARAN}

1. Bagi Mahasiswa

Hasil penelitian ini diharapkan menjadi masukan kepada mahasiswa tentang penggunaan kolagen tulang ikan patin sebagai pelembab kulit

2. Bagi pendidikan

Hasil penelitian ini diharapkan menjadi informasi tambahan bagi instansi pendidikan

3. Bagi penelitian selanjutnya

Diharapkan untuk membuat variasi dan menambahkan variable lain dari kolagen ikan terhadap pembuatan lotion sebagai pelembab kulit

\section{REFERENSI}

Balsam, M. S. (1972). Cosmetic Science and Technology. Edisi II. New York: John Wiley and Son, Inc. Halaman 179.

Cahyanto, A. (2009). Biomaterial. Bandung: Universitas Padjadjaran. Halaman 65

Departemen Kesehatan RI. (1985). Formularium Kosmetika Indonesia. Jakarta: Departemen Kesehatan RI. Halaman 23.

Hua-Jie, W., Ling, D., Qiu-Shi, D dan JinYe, W. (2009). Applications and Degradation of Proteins Used as Tissue Engineering Materials. Journal. Shanghai: Biomedical Engineering, School of Life Science 
and Biotechnology, Shanghai Jiao Tong University. Halaman 614.

Iswari, T. R. (2007). Buku Pegangan

Ilmu Pengetahuan Kosmetik.

Jakarta: Gramedia Pustaka Utama. Halaman 7.

Kittiphattanabawon, P., Benjakul, S., Visessanguan, W., Nagai, $T$ dan Tanaka, M. (2005). Characterisation of Acid-Soluble Collagen From Skin and Bone of Bigeye Snapper (Priacanthus tayenus). Journal Food Chemistry. Thailand: 89(3): 363.

Kordi, M. G. H. (2005). Budidaya Ikan Patin Biologi, Pembenihan dan Pembesaran. Yogyakarta: Yayasan Pustaka Nusatama. Halaman 87.

Muliyawan, D dan Suriana, N. (2002). A-Z Tentang Kosmetik. Jakarta: Elex Media Kompotindo.

Pringgandini, L. A., Indarti, G. Y., Melinda dan Sari, M. (2018). Efektifitas Spray Nanokolagen Limbah Sisik Ikan Mas (Cyprinus carpio) untuk Mempercepat Proses Penyembuhan Luka Insisi. Laporan Penelitian. Departemen Ilmu Kesehatan Gigi Masyarakat, Fakultas Kedokteran Gigi, Universitas Muhammadiyah Surakarta.

Susanto, H dan K, Amri. (2008). Budi Daya Ikan Patin. Jakarta: Penebar Swadaya. Halaman 90.

Voigt, R. (1995). Buku Pelajaran Teknologi Farmasi. Yogyakarta: UGM Press. Halaman 89.

Wasitaatmadja, S.M. (1997). Penuntun Ilmu Kosmetik Medik. Jakarta: Universitas Indonesia. Halaman 63.

Wilkinson. (1982). Herry's Cosmeticology. London: George Godwin. 